\title{
PROSEDUR PENANGANAN SURAT KELUAR DI BAGIAN TATA USAHA PADA LEMBAGA PENDIDIKAN SMP AL-HASRA DEPOK
}

\author{
Oleh : Edi Junaedi, SE., MM. \& Historia S \\ Junaedi_salat1@yahoo.com
}

\begin{abstract}
Abstrak
Ketertiban dan kelancaran merupakan beberapa faktor penting dalam kepengurusan administrasi. Dalam kepengurusan ketatausahaan organisasi seperti instansi pemerintah ataupun swasta, dituntut terjaganya kelancaran administrasi guna menunjang keefektifan kinerja dan terpenuhi akan manfaat yang diinginkan. Tata usaha adalah segenap aktifitas menghimpun, mencatat, mengolah mengirim dan menyimpan keterangan-keterangan yang diperlukan dalam setiap organisasi.
\end{abstract}

Kata Kunci : Administrasi, keefektifan kinerja, organisasi

\section{PENDAHULUAN}

\section{Latar Belakang Masalah}

Salah satu tugas tata usaha dari pengertian diatas berkaitan dengan keterangan, surat menyurat dan warkat-warkat, oleh karena itu tata usaha sering disebut pekerjaan tulis menulis maka tercipta warkat yang kemudian terkumpul menjadi arsip.

Prosedur pengolahan surat perlu diterapkan untuk masing-masing unit organisasi, karena merupakan sumber data atau informasi yang bermanfaat untuk kemajuan organisasi tersebut secara maksimal. Sumber data atau informasi yang digunakan adalah surat. Surat adalah alat komunikasi tertulis yang berasal dari satu pihak dan ditujukan kepada pihak lain untuk menyampaikan warta (Bartos, 2003:36).

Menurut Kamus Besar Bahasa Indonesia Dalam Kamus Besar Bahasa Indonesia disebutkan pengertian surat adalah kertas yang bertulis, secarik kertas sebagai tanda atau keterangan, sesuatu yang ditulis atau tertulis.

Surat masih digunakan sampai sekarang karena surat masih memiliki kelebihan dibandingkan dengan sarana komunikasi lainnya, kelebihan tersebut karena surat lebih praktis, efektif dan ekonomis. Surat selain berfungsi sebagai alat komunikasi juga berfungsi sebagai pengingat, bahan bukti hitam diatas putih yang memiliki kekuatan hukum, sumber data, alat pengingat, jaminan, wakil, alat promosi. 
Dalam suatu organisasi / perusahaan surat menurut prosedur pengurusannya dibagi menjadi dua yaitu surat masuk dan surat keluar. Surat masuk adalah semua jenis surat yang diterima dari instansi lain maupun perorangan, baik yang diterima melalui pos maupun yang diterima melalui kurir dengan mempergunakan buku pengiriman / ekspedisi, sedangkan surat keluar adalah surat yang sudah lengkap (bertanggal, bernomor, berstempel, dan telah ditanda tangani oleh pejabat yang berwenang) yang dibuat oleh suatu instansi, kantor atau lembaga untuk ditujukan atau dikirim kepada instansi, kantor atau lembaga lain (Wursanto, 2003 : 104).

Surat adalah sehelai kertas atau lebih yang memuat suatu bahan komunikasi yang disampaikan oleh seseorang kepada orang lain baik atas nama pribadi maupun kedutaan dalam organisasi kantor. (Suhanda Panji, 1997, Manajemen, FOKUSMEDIA, 38)

Surat keluar adalah segala komunikasi tertulis yang diterima oleh suatu badan usaha dari instansi lain atau perorangan ( Wursanto, 1991 :144 ). Darji (1978: 8) mengemukakan bahwa surat adalah suatu sarana untuk menyampaikan informasi atau pernyataan secara tertulis kepada pihak lain baik atas nama sendiri ataupun jabatannya dalam organisasi.

(Agus Sugiarto, 2005:2) Surat sebagai suatu sarana komunikasi yang digunakan untuk menyampaikan informasi tertulis oleh suatu pihak kepada pihak lain. Dengan lebih jelasnya, Surat adalah alat komunikasi tertulis untuk menyampaikan pesan kepada pihak lain yang memiliki persyaratan khusus yaitu penggunaan kertas, penggunaan model/bentuk, penggunaan kode dan notasi, pemakaian bahasa yang khas serta pencantuman tanda tangan.

Surat adalah alat komunikasi tertulis yang berasal dari satu pihak dan ditujukan kepada pihak lain untuk menyampaikan berita/informasi. Ini menunjukkan betapa pentingnya pengelolaan surat yang baik secara efektif dan efisien.

Pengurusan surat menyurat dalam suatu kantor adalah hal terpenting. Pengurusan surat menyurat berbeda dari satu instansi ke instansi yang lain. Dalam suatu instansi yang besar pengurusan surat-menyurat dapat dikerjakan

secara sentralisasi maupun desentralisasi.

Surat keluar adalah surat yang dibuat oleh suatu perusahaan atau organisasi untuk ditujukan atau dikirim kepada perusahaan/instansi/lembaga lain maupun perorangan. Penanganan surat keluar harus dilakukan secara praktis dan efisien sehingga surat-surat keluar dapat tersusun secara rapih dan akan mempermudah pencarian kembali pada saat surat keluar tersebut dibutuhkan. Pendistribusian /Pengiriman surat keluar meliputi, mempersiapkan redaksi isi surat, menulis nomor sesuai di buku agenda keluar, mengetik surat sesuai redaksi yang telah 
diberikan oleh Pimpinan, selesai itu tanda tangan dan cap stempel, fotokopi surat untuk arsip dan surat keluar didistribusikan kepada alamat yang dituju.

Salah satu tugas sekretaris dalam melaksanakan instruksi adalah melakukan pengiriman, penerimaan surat, karena pengiriman, penerimaan surat merupakan salah satu aktivitas organisasi atau perusahaan yang sering dilakukan untuk memberikan informasi dan menerima informasi. Agar pelaksanaan surat keluar dapat berjalan secara efektif dan efisien, maka perlu dilakukan pengrekapan pada surat-surat keluar dan masuk, sehingga tidak ada surat keluar yang tidak lengkap dengan buku agenda surat keluar. Oleh karena itu, seberapapun pentingnya suatu pekerjaan apabila tidak mampu menyusunnya dengan baik, maka hasilnya juga akan kurang memuaskan.

Selain berfungsi sebagai alat komunikasi, surat juga berfungsi sebagai wakil dari pembuatan surat, dan sebagai bukti secara tertulis yang memiliki kekuatan hukum. Secara umum juga dapat dikatakan bahwa surat adalah alat untuk menyampaikan suatu maksud secara tertulis.

Walaupun kegiatan surat menyurat dipandang sebagai suatu kegiatan yang mudah, namun surat menyurat merupakan salah satu dari kegiatan yang bisa menunjang tercapainya tujuan lembaga/organisasi.

\section{Identifikasi Masalah}

Berdasarkan latar belakang masalah yang telah diuraikan, maka akan dibahas permasalahan-permasalahan yang berkaitan dengan Prosedur Penanganan Surat Keluar Pada Lembaga Pendidikan SMP Al-Hasra Depok meliputi :

1. Macam-macam surat keluar pada Lembaga Pendidikan SMP Al-Hasra.

2. Fungsi surat mempengaruhi kelancaran informasi pada Lembaga Pendidikan SMP AlHasra.

3. Prosedur penanganan surat keluar.

\section{Perumusan Masalah}

Dari batasan masalah tersebut, dapat dirumuskan beberapa masalah sebagai berikut :

1. Apa saja macam-macam surat keluar pada Lembaga Pendidikan SMP Al-Hasra?

2. Apa pengaruh fungsi surat untuk memperlancar informasi pada Lembaga Pendidikan SMP Al-Hasra? 
3. Langkah-langkah apa saja dalam prosedur penanganan surat keluar pada Lembaga Pendidikan SMP Al-Hasra?

\section{Tujuan Penulisan}

Tujuan yang diharapkan untuk menyelesaikan masalah yang ada pada suatu lembaga adalah :

1. Untuk mengetahui macam-macam surat keluar pada Lembaga Pendidikan SMP Al-Hasra.

2. Untuk mengetahui fungsi surat demi kelancaran informasi pada Lembaga Pendidikan SMP Al-Hasra.

3. Untuk mengetahui prosedur pengurusan surat keluar pada Lembaga Pendidikan SMP AlHasra.

\section{Metode Penulisan}

Untuk mendapatkan data yang dibutuhkan, Penulis menggunakan beberapa metode, yaitu sebagai berikut :

1. Observasi (Pengamatan)

Patton (1990: 201 dalam Poerwandari, 1998: 63) menegaskan observasi merupakan metode pengumpulan data esensial dalam penelitian, apalagi penelitian dengan pendekatan kualitatif. Agar memberikan data yang akurat dan bermanfaat, observasi sebagai metode ilmiah harus dilakukan oleh peneliti yang sudah melewati latihan-latihan yang memadai, serta telah mengadakan persiapan yang teliti dan lengkap.

2. Interview (Wawancara)

(Lexy J Moleong 1991:135) dijelaskan bahwa wawancara adalah percakapan dengan maksud-maksud tertentu. Pada metode ini peneliti dan responden berhadapan langsung (face to face) untuk mendapatkan informasi secara lisan dengan tujuan mendapatkan data yang dapat menjelaskan permasalahan penelitian

\section{TINJAUAN PUSTAKA}

\section{Pengertian Prosedur}

"Prosedur adalah suatu urutan kegiatan klerikal, biasanya melibatkan beberapa orang dalam suatu departemen atau lebih yang dibuat untuk menjamin penanganan secara seragam transaksi perusahaan yang terjadi berulang-ulang. Didalam suatu sistem, biasanya terdiri dari beberapa prosedur dimana prosedur-prosedur itu saling terkait dan saling 
mempengaruhi. Akibatnya jika terjadi perubahan maka salah satu prosedur, maka akan mempengaruhi prosedur-prosedur yang lain”. (Mulyadi (2001:5)).

"Prosedur merupakan urutan pekerjaan klerikal yang melibatkan beberapa orang dalam suatu bagian atau lebih, disusun untuk menjamin adanya perlakuan yang seragam terhadap transaksi yang sering terjadi.” (Zaki Baridwan (1990:3)).

Prosedur adalah serangkaian aksi yang spesifik, tindakan atau operasi yang harus dijalankan atau dieksekusi dengan cara yang baku (sama) agar selalu memperoleh hasil yang sama dari keadaan yang sama, semisal prosedur kesehatan dan keselamatan kerja. Menghasilkan suatu tujuan yang diinginkan, suatu produk atau sebuah akibat. Sebuah prosedur biasanya mengakibatkan sebuah perubahan.

Prosedur adalah peraturan. Dalam pengertian yang lebih lengkap, prosedur adalah aturan bermain, aturan bekerja sama, aturan berkoordinasi, sehingga unit-unit dalam sistem, subsistem, subsubsistem, dan seterusnya dapat berinteraksi satu sama lain secara efisien dan efektif. Misalnya, prosedur kepegawaian diatur oleh peraturan kepegawaian, prosedur lalu lintas jalan diatur oleh Undang-undang Lalu Lintas. Sedangkan, menurut The Macquarie Dictionary, prosedur adalah perbuatan atau cara kerja dalam segala tindakan atau proses.

\section{Pengertian Surat Menyurat}

Secara umum surat adalah suatu sarana untuk menyampaikan informasi atau pernyataan secara tertulis kepada pihak lain baik atas nama pribadi (sendiri) ataupun karena kedinasan. Surat juga merupakan wakil resmi dari yang mengirim untuk membicarakan masalah yang dihadapi. Secara singkat dapat diketemukan bahwa surat adalah alat komunikasi penting dalam tata kerja tata usaha. Apabila terjadi hubungan surat menyurat secara terus menerus dan berkesinambungan, maka kegiatan ini disebut surat menyurat atau lazimnya korespondensi.

Surat menyurat adalah suatu kegiatan untuk mengadakan hubungan secara terus menerus antara pihak yang satu kepada pihak yang lainnya. Dan dilaksanakan dengan saling berkiriman surat. Kegiatan surat menyurat ini disebut juga dengan istilah lainnya yaitu korespondensi.

Jika hanya sepihak saja yang mengirimkan surat secara terus menerus tanpa ada balasan atau tanggapan dari pihak lainnya hal ini tidak dapat dinamakan kegiatan surat menyurat. Setiap kerja perorangan apalagi organisasi selalu membutuhkan kerja sama dengan pihak lain untuk mencapai tujuannya. 


\section{Fungsi Surat Menyurat}

Surat yang berfungsi sebagai salah satu alat komunikasi dalam dunia usaha dan perkantoran, dapat juga berfungsi sebagai :

a. Alat bukti tertulis : adanya hitam di atas putih berguna untuk dijadikan bukti apabila terjadi perselisihan atau salah penafsiran antar kantor atau pejabat yang mengadakan hubungan korespondensi.

b. Alat pengingat : berguna untuk mengetahui hal-hal yang terlupa atau telah lama.

c. Bukti historis : berguna sebagai bahan riset mengenai keadaan atau aktivitas suatu organisasi pada masa-masa lalu.

d. Duta organisasi : surat dapat mencerminkan keadaan mentalitas, jiwa dan kondisi intern dari organisasi atau kantor yang bersangkutan.

e. Pedoman : surat juga merupakan pedoman dalam pelaksanaan pekerjaan.

\section{Jenis-Jenis Surat Menyurat}

a. Berdasarkan Pemakaian, jenis surat dibagi menjadi :

1) Surat Pribadi

Surat pribadi adalah surat yang dipergunakan untuk kepentingan pribadi. Isi surat berhubungan dengan urusan pribadi. Contohnya surat seorang anak kepada orang tuanya atau surat kepada teman.

Ciri-ciri surat pribadi seperti berikut.

a) Tidak menggunakan kop surat/kepala surat

b) Tidak menggunakan nomor surat

c) Salam pembuka dan penutup surat bervariasi

d) Penggunaan bahasa bebas, sesuai dengan keinginan si penulis surat.

e) Format surat bebas

2) Surat Resmi

Surat resmi ialah surat yang dipergunakan untuk kepentingan yang bersifat resmi, baik yang ditulis dari perseorangan, instansi, lembaga, maupun organisasi. Contohnya: surat undangan, surat pemberitahuan, dan surat edaran.

Ciri-ciri surat resmi, seperti berikut :

a) Menggunakan kepala surat jika yang mengeluarkannya adalah lembaga atau organisasi 
b) Menggunakan nomor surat, lampiran, dan perihal

c) Menggunakan salam pembuka dan penutup yang lazim atau resmi, seperti: Assalamualikum, dengan hormat, hormat kami

d) Menggunakan bahasa dengan ragam resmi atau baku

e) Menggunakan cap/stempel jika berasal dari sebuah organisasi atau lembaga resmi

f) Penulisan surat mengikuti format surat tertentu (tidak bebas)

3) Surat Dinas

Surat dinas ialah surat yang dipergunakan untuk kepentingan pekerjaan, tugas dari kantor, atau kegiatan dinas. Surat ini berasal dari instansi atau lembaga baik swasta maupun negeri. Contoh: surat tugas, surat perintah, memorandum, dan surat keputusan. Surat dinas yang berifat perseorangan ialah surat lamaran pekerjaan, surat permohonan izin, dan surat permohonan cuti.

Ciri-ciri surat dinas, seperti berikut.

a) Menggunakan kop/kepala surat dan instansi atau lembaga yang bersangkutan

b) Menggunakan nomor surat, lampiran, dan perihal

c) Menggunakan salam pembuka dan penutup yang baku atau resmi, seperti : dengan hormat, hormat kami

d) Menggunakan bahasa baku atau ragam resmi

e) Menggunakan cap/stempel instansi atau kantor pembuat surat

4) Surat Lamaran Pekerjaan

Surat lamaran pekerjaan dapat ditulis tangan atau diketik. Adakalanya suatu perusahaan atau instansi tertentu mensyaratkan secara khusus agar surat lamaran yang dikirimkan pelamar ditulis tangan atau diketik. Kalaupun surat lamaran pekerjaan akan ditulis tangan, tulisan tersebut hendaknya jelas, mudah dibaca, dan rapi. Surat yang ditulis seperti itu akan memudahkan orang yang membacanya.

b. Berdasarkan Pembuatan Surat

1) Surat Pribadi

Jenis surat ini ditulis atas nama pribadi seseorang serta berisi masalah pribadi penulis, baik yang ditujukan kepada teman, keluarga maupun instansi tertentu. 
Contoh surat ini adalah surat untuk keluarga, surat lamaran kerja, dan surat permohonan izin bangunan.

2) Surat Resmi

Surat resmi dibuat suatu instansi, organisasi atau lembaga perusahaan tertentu yang ditujukan kepada seseorang atau lembaga tertentu lainnya. Keberadaan instansi, lembaga, organisasi dan perusahaan tersebut disahkan secara hukum. Contoh surat resmi adalah surat dinas, surat niaga, dan surat sosial.

\section{c. Berdasarkan Pesan Surat}

1) Surat Keluarga

Surat keluarga adalah surat yang berisi masalah-masalah keluarga atau kekeluargaan. Contoh surat keluarga adalah surat untuk orang tua, saudara, dan teman.

2) Surat Setengah Resmi

Surat setengah resmi adalah surat yang dikirimkan oleh seseorang kepada instansi atau lembaga organisasi tertentu. Jenis surat ini misalnya surat lamaran kerja, permohonan IMB dan surat permohonan cuti.

3) Surat Sosial

Surat sosial adalah surat yang dibuat oleh lembaga sosial kepada seseorang, organisasi, atau instansi tertentu yang biasanya berisi berbagai masalah sosial. Misalnya, surat permintaan sumbangan dan edaran untuk kerja bakti.

4) Surat Niaga

Surat niaga adalah surat yang ditulis oleh suatu perusahaan perniagaan dengan pesan berniaga. Contoh jenis surat ini adalah surat penawaran harga, penagihan utang, lelang barang, atau pesanan barang.

5) Surat Dinas

Surat ini berisikan masalah kepemerintahan atau kedinasan dari suatu lembaga atau keorganisasian. Surat ini dapat ditujukan kepada instansi lain, perorangan dan organisasi tertentu. Misalnya, surat keputusan, surat perintah, dan surat tugas.

6) Surat Pengantar

Surat ini ditujukan kepada perorangan atau lembaga sebagai pengatur atau referensi seseorang untuk berhubungan dengan pihak penerima surat. 
d. Berdasarkan Keamanan Pesan Surat

1) Surat Sangat Rahasia

Surat ini berisi pesan dokumen penting yang berkaitan dengan rahasia atau keamanan suatu negara. Jenis surat ini dikirim dengan menggunakan tiga buah sampul. Pada sampul pertama dituliskan kode SR yang merupakan singkatan dari "Sangat Rahasia". Pada sampul kedua dituliskan kode SRS, yaitu singkatan dari "Sangat Rahasia Sekali" serta dibubuhi segel atau lak untuk membuktikan keutuhan pesan surat. Pada sampul terakhir (luar) dibuat biasa agar tidak mengundang kecurigaan orang lain. Surat jenis ini, misalnya surat dari kementerian luar negeri, surat untuk negara-negara tetangga, dan surat dokumen kemiliteran.

2) Surat Rahasia

Jenis surat ini berisi dokumen ringan yang pesannya hanya pantas diketahui oleh satu atau beberapa pejabat tertentu atau yang berwenang pada sebuah instansi. Pengiriman surat ini menggunakan dua buah sampul. Sampul pertama dituliskan kode R atau RS yaitu singkatan dari "Rahasia" atau "Rahasia Sekali" serta disegel, sedangkan sampul kedua tidak diberi kode apa pun. Surat jenis ini misalnya surat tentang konduet pejabat dan surat dokumen suatu instansi.

3) Surat Konfidensial

Surat yang isinya hanya layak diketahui oleh beberapa pejabat tertentu sebab pesannya memerlukan tindakan kebijaksanaan dari para pejabat tersebut. Misalnya surat hasil rapat pimpinan dan usulan kenaikan pangkat seseorang.

4) Surat Biasa

Surat biasa adalah surat yang pesannya dapat diketahui oleh orang lain tanpa mengakibatkan kerugian bagi pihak mana pun. Misalnya, surat edaran dan surat undangan.

e. Berdasarkan Penyelesaian Surat

1) Surat Kilat

Surat kilat adalah surat yang pesannya harus dapat disampaikan kepada penerima surat secepat mungkin. Tanggapan yang diharapkan dari surat tersebut pun perlu dilakukan dengan cepat. 
2) Surat Segera

Pesan dalam jenis surat ini perlu segera disampaikan kepada penerima surat, tetapi tidak harus dikerjakan atau ditanggapi dengan cepat seperti pada surat kilat.

3) Surat Biasa

Jenis surat ini baik cara pembuatan atau pengirimannya tidak harus diprioritaskan seperti kedua jenis surat di atas.

\section{Pengertian Tata Usaha}

"Tata Usaha" memiliki beberapa pengertian, tetapi semuanya hampir memiliki arti yang sama yang mengarah pada pengaturan tata menulis dan cata mencatat. Berikut beberapa pengertian tentang "Tata Usaha". Ditinjau dari asal katanya: "Tata Usaha" terdiri dari kata "Tata" dan "Usaha", masing-masing memiliki pengertian: "Tata" adalah suatu peraturan yang harus ditaati, dan "Usaha" ialah energi/tenaga yang dikeluarkan untuk tercapainya suatu maksud/tujuan.

Jadi menurut arti kata, "Tata Usaha" ialah suatu peraturan yang terdapat dalam suatu proses penyelenggaraan kerja. Dalam Kamus Bahasa Indonesia: "Tata Usaha" ialah penyelenggaraan tulis menulis (keuangan dan sebagainya) di perusahaan, negara dan sebagainya, sedangkan "penata usaha ialah" orang yang menyelenggarakan tata usaha.

The Liang Gie dalam buknya Administrasi Perkantoran Modern : "Tata Usaha" ialah segenap rangkaian aktivitas menghimpun, mencatat, mengelola, mengadakan, mengirim, dan menyimpan keterangan-keterangan yang diperlukan dalam setiap usaha kerja. Dalam arti sempit, "Tata Usaha" juga dapat diartikan sebagai kegiatan untuk mengadakan pencatatan dan penyusunan keerangan-keterangan, sehingga keterangan-keterangan tersebut dapat digunakan secara langsung sebagai bahan informasi bagi pimpinan suatu organisasi yang bersangkutan dan juga oleh siapa saja yang membutuhkannya.

Tata usaha adalah kegiatan yang dilakukan meliputi, membantu proses belajar mengajar, urusan kesiswaan, kepegawaian, peralatan sekolah, urusan infrasturcture sekolah, keuangan, bekerja di laboratorium, perpustakaan dan hubungan masyarakat (Sumber: hasil rapat Kepala Tata Usaha di Bogor: 1996).

Tata usaha (kantor) adalah tempat/gedung atau ruangan yang digunakan untuk melakukan pekerjaan tulis menulis dan dilengkapi dengan fasitilas penunjang. Sehingga, 
dalam pengertian sehari-hari, kantor dapat diberikan kepada beberapa tempat sebagai berikut :
a. Ruang kerja,
b. Pusat kegiatan untuk mengatur bisnis dalam sebuah perusahaan,
c. Badan usaha, instansi pemerintah, dan lain-lain.

Menurut Moch. Rifai (1987: 51) dalam Baharudin (2004: 215) administrasi tata usaha adalah salah satu kegiatan administrasi pendidikan di sekolah. Dalam bahasa Inggris istilah tata usaha di sebut dengan "clerical work" office menegement or recording and report system.

Yang mengandung pengertian yaitu kegiatan administrasi pendidikan yang mengelola pencatatan, penmgumpulan, penyimpanan data, dan dokumen yang dapat dipergunakan untuk membentu pimpinan dalam pengambilan keputusan, urusan surat menyurat serta laporan mengenai kegiatan sekolah tersebut.

\section{Kegiatan Dalam Ketatausahaan}

Menurut Prajudi Atmosudirjo (1976: 159) kegiatan ketatausahaan meliputi: Perencanaan, koordinasi, pengendalian, monitoring dan evaluasi kegiatan ketatausahaan dan administrasi.

a. Menyusun program kerja ketatausahaan atau administrasi kelancaran (bulanan,triwulan, semesteran dan tahunan) dalam rangka kegiatan ketata usahaan/ administrasi;

b. Melaksanakan kegiatan pengelolaan keuangan/dana, sarana, administrasi ketatausahaan, kepegawaian dan statistik sekolah, sesuai dengan petunjuk atau pedoman dan peraturan yang berlaku untuk mencapai tujuan pelayanan administrasi yang baik;

c. Mengelola tugas rutin ketata usahaan, antara lain: surat menyurat,inventarisasi, dokumentasi atau agenda, pembukuan keuangan, administrai kepegawaian dan sarana; Mengatur dan mendokumentasikan presensi pegawai, penyajian data statistik, pembuatan laporan rutin atau insidental, dan menghimpun data administrasi sekolah; pegawai tata usaha dan teknisi dalam kelancaran pelaksanaan tugas sesuai tanggung jawab masing-masing;

d. Mengkoordinasikan, pembagian kerja timbul disebabkan bahwa seseorang mempunyai kemapuan terbatas untuk melakukan segala macam pekerjaan. Oleh 
Karena itu pembagian kerja berarti bahwa kegiatan-kegiatan dalam melakukan pekerjaan harus ditentukan dan dikelompokkan agar lebih efektif dalam pencapaian tujuan organisasi.

Menurut G.R. Terry koordinasi adalah suatu usaha yang sinkron dan teratur untuk menyediakan jumlah dan waktu yang tepat, dan mengarahkan pelaksanaan untuk menghasilkan suatu tindakan yang seragam dan harmonis pada sasaran yang telah ditentukan.

\section{PEMBAHASAN DAN HASIL}

\section{Sejarah Yayasan Al-Hasra (SMP-SMA-SMK Al-Hasra)}

Perubahan sosial budaya masyarakat Indonesia melalui proses yang lebih dikenal dengan istilah "pembangunan nasional", pada gilirannya tidak hanya berpengaruh terhadap tatanan fisik material dan sosiokultural saja, tetapi juga sangat mempengaruhi kehidupan spiritual umat Islam di Indonesia. Dalam perkembangan kehidupan sosial budaya seperti ini, agama (baca : Islam) yang semula dianggap dan diharapkan berfungsi sebagai sumber inspirasi kehidupan umat. Justru ditantang untuk menciptakan bentuk-bentuk ekspresi dan istitusi yang baru, yaitu ekspresi ataupun bentuk institusi yang sesuai dengan perkembangan kebudayaan modern dewasa ini.

Kemampuan untuk melahirkan ekspresi dan institusi baru akan membuat islam mampu berperan dan bermakna bagi peletakan dasar-dasar etika kehidupan umat khususnya umat Islam.

Tetapi sebaliknya, ketidakmampuan agama menyesuaikan diri dengan perkembangan modern akan berakibat pada semakin jauhnya umat dari agamanya, agama bisa-bisa kehilangan makna ditengah-tengah kehidupan yang semakin sekuler ini. Dan tampaknya gejala yang terakhir inilah yang umum terjadi pada dunia Islam dewasa ini.

Kualitas sumber daya manusia yang belum emungkinkan umat islam mengambil peran aktif dalam proses pembangunan. Umat islam tidak lebih sebahai pemakai hasil pembangunan ketimbang menjadi pelaku pembangunan yang berpartisipatif.

Atas dasar pemikiran diatas, timbulah cita-cita pada diri Bapak Haji Hashuda. Setelah beliau mendapat cobaan dari Allah SWT. Yang hampir merengut jiwanya pada hari jum'at, 11 maret 1977 sekitar pukul 15.00 wib, sewaktu pulang melihat restoran yang berada di wilayah sukabumi, Jawa Barat. 
Kejadian tersebut terjadi ketika mobil yang ia tumpangi bersama sopirnya meluncur dengan kencangnya di jalan raya desa klari krawang, tiba-tiba slip jungkir balik dan berputar-putar sejauh kurang lebih 30 meter. Mobil tersebut baru berhenti setelah masuk kedalam got dengan posisi terbalik, musibah yang menimpa beliau tersebut mengakibatkan meninggalnya sang sopir seketika itu juga. Kejadian tersebut dimaknai beliau sebagai peringatan dari Allah baginya, dengan hikmah agar beliau tidak hanya memikirkan kepentingan dunia semata tetapi juga harus mempersiapkan diri untuk bekal kehidupan akhirat yang telah dijanjikan Allah kekal didalamnya.

Lima tahun berlalu impian dari Bapak H. Hashuda belum juga terwujud. Hingga pada pagi hari yang cerah di bulan Januari tahun 1982, ketika H. Hashuda sedang duduk di depan restorannya di Jalan Matraman Raya No. 65 Jatinegara Jaktim, tiba-tiba saja seseorang yang baru saja menyelesaikan makan pagi di restoran tersebut melontarkan perkataan, "apakah pak Haji tidak berniat untuk mendirikan masjid?", mendapat pertanyaan seperti itu, Bapak H. Hashuda seolah mendapatkan sebuah gagasan, segera mempersilahkan orang tersebut.

Setelah ada perbincangan singkat diketahui ternyata orang tersebut adalah mantan anggota polisi yang selalu menyampaikan gagasan kepada pemuka masyarakat atau siapa saja yang mungkin menerima ide-idenya. Ia mengatakan bahwa dia sekarang sedang mengerjakan sebuah masjid di wilayah Depok dengan anggaran Rp. 100.000.000,- (seratus juta rupiah) atas prakarsa seorang dermawan dari Jakarta.

Orang tersebut berkata "Kalau Pak Haji ada atau mempuyai waktu, mari kita lihat kesana" ucapnya. Bapak Haji Hashuda meresponinya dan langsung melihat masjid yang sedang di bangun orang tersebut. Sepulang dari sana Bapak Haji Hashuda tidak sengaja melihat dan tertarik pada sebidang tanah yang akan dijual di pinggir jalan raya SawanganParung yang saat itu masuk ke dalam wilayah administarsi kota Bogor.

Setelah proses penjajakan kepada pemilik tanah, maka terjadilah transaksi jual-beli yang dilaksanakan pada tanggal 22 Januari 1982. untuk mencari solusi (jalan keluar) dari problematika atas tanah yang telah tersedia, sesuai dengan kemampuan dan ketersedian sumber daya yang ada semula difahami bahwa jalan keluar dari problematika itu dapat dilakukan dengan pendekatan usaha dibidang ekonomi (restoran) atau dibidang kesehatan (rumah sakit/klinik) tetapi perkembangan analisa selanjutnya menunjukan bahwa untuk merambah kedua bidang tersebut belum didukung oleh ketersediaan sumber daya yang efektif, disamping pertimbangan bahwa kedua bidang tersebut belum secara langsung 
menjawab keprihatinan spiritual umat Islam seperti yang digambarkan di atas menjadi landasan berpikir berdirinya sebuah badan hukum (yayasan) sosial.

Akhirnya diputuskan bahwa bidang pendidikan adalah bidang yang paling tepat untuk menjawab persoalan tersebut. Karena dipahami keprihatinan sosial spiritual dan kemiskinan intelektual yang melanda umat islam akan lebih tepat jika didekati melalui upaya-upaya peningkatan penguasaan keilmuan yang dilakukan secara terencana, terprogram, terorganisir dan dengan kemampuan pengelolaan manajemen modern.

Untuk memenuhi kebutuhan dan permintaan masyarakat, maka pada tahun 1987 Yayasan Pendidikan Al-Hasra, membuka Sekolah Menengah Tingkat Atas (SMA), dengan kepala sekolah Bapak Muzahar Jalil. Dengan jumlah siswa pertama kali sebanyak 16 orang, SMA Al-Hasra terus menerus berusaha meningkatkan kualitas pendidikannya sehingga dari tahun ketahun terjadi peningkatan kuantitas siswa yang masuk ke SMA Al-Hasra. Pada tahun 1999 berdiri pula Sekolah Menegah Kejuruan (SMK) Al-Hasra dengan dua pilihan program diklat yang ditawarkan yaitu Program Diklat Penjualan dan Administrasi Perkantoran yang bertujuan mempersiapkan siswa yang kompeten untuk bekerja sesuai dengan bidang yang diajarkan. Disusul dengan penambahan program diklat Perbankan Syariah pada tahun 2005 yang untuk pertama kalinya diadakan dikota Depok.

Peningkatan mutu dan kualitas pendidikan, baik SMP, SMA maupun SMK menjadi agenda yang dilakukan secara berkesinambungan.

Disadari betul bahwa lembaga pendidikan sekolah Al-Hasra harus mampu berada di garda paling depan perkembangan dunia pendidikanIndonesia, dan itu hanya mungkin jika diikuti dengan kemampuan untuk mengantisipasi setiap perkembangan sains dan teknologi yang di dasari oleh nilai-nilai spiritual islam yang kuat. Kesadaran itu kemudian dijabarkan melalui kerangka kerja yang terencana dan terprogram, baik menyangkut pembinaan tenaga edukatif, peningkatan proses belajar mengajar maupun penciptaan suasana yang kondusif bagi terselenggaranya proses pendidikan dengan lancar dan tertib.

Upaya kearah itu, yang telah dilakukan antara lain:

a. Melakukan pembinaan terhadap mutu tenaga edukatif SMP, SMA dan SMK Al-Hasra secara terprogram dan terencana dengan alokasi dana yang disesuaikan dengan kebutuhan dan kemampuan yayasan

b. Menambah dan meningkatkan mutu dan jumlah koleksi buku-buku di perpustakaan SMP, SMA dan SMK Al-Hasra yang diharapkan dapat merangsang minat baca serta 
untuk membangun tradisi keilmuan yang harus ditumbuhkembangkan sedini mungkin dalam diri siswa Al-Hasra dan meningkatkan prestasi belajar siswa.

c. Menambah dan terus menerus menyediakan peralatan serta bahan laboratorium IPA yang akan mengundang gairah siswa untuk melakukan riset dan pembuktianpembuktian ilmiah secara terarah dan mendalam

d. Mengadakan kegiatan-kegiatan ekstrakurikuler yag memungkinkan siswa dapat mengembangkan kepribadian dan kemampuannya dalam bidang kepempinan, keorganisasian, kesenian, keterampilan dan kemasyarakatan sehingga tercipta dinamika kehidupan akademik dan kesiswaan yang sehat dan konstruktif

e. Membimbing siswa agar terampil dalam penggunaan / pengelolaan teknologi informasi dan komunikasi dengan upaya menambah dan terus menerus menyediakan peralatan teknologi informasi dan komunikasi di laboratorium komputer sesuai dengan perkembangan teknologi, serta memberikan pelatihan keterampilan penggunaan / pengelolaan teknologi informasi dan komunikasi bagi guru maupun karyawan SMP, SMA dan SMK Al-Hasra

f.Melengkapi instrument musik di laboratorium musik Al-Hasra dengan berbagai instrument musik dengan tujuan untuk mengasah ketajaman rasa dan apresiasi seni khususnya seni musik siswa Al-Hasra. Melalui musik, kehalusan jiwa dan budi pekerti siswa di latih. Melalui nusik pula, bakat da minat siswa disalurkan menjadi sebuah keterampilan hidup yang yang bermanfaat dan berguna kelak.

g. Menciptakan suasana yang kondusif dan segar bagi terlaksananya proses belajar mengajar.

h. Penataan dan pelayanan administrasi sekolah SMP, SMA dan SMK yang lebih baik kea rah manajemen administrasi berbasis teknologi informasi dan komunikasi

i. Menyusun serta menyiapkan program publikasi Al-Hasra secara terencana dan terprogram untuk setiap tahunnya.

j. Meningkatkan kualitas hubungan dan komunikasi dengan menciptakan kegiatankegiatan yang yang memungkinkan terjalinnya hubungan yang harmonis dan positif antara sekolah dengan masyarakat lingkungannya. 


\section{Visi dan Misi SMP Al-Hasra}

\section{$\underline{\text { Visi }}$}

“Terwujudnya lulusan pendidikan dasar yang islami, mampu menguasai teknologi dan bahasa asing”.

\section{Misi}

1. Melaksanakan pendidikan dasar dengan menanamkan nilai-nilai islami

2. Meningkatkan kemampuan penguasaan sains teknologi dan bahasa asing

3. Mengembangkan potensi peserta didik di bidang akademik dan non akademik.

\section{Company Data}

1. Name of Company

: Lembaga Pendidikan SMP Al-Hasra

2. Address

: Jalan Raya Ciputat - Parung KM.24, Kelurahan

Bojongsari Baru, Kecamatan Bojongsari - Kota Depok

\section{PEMBAHASAN DAN HASIL}

Pada pembahasan dan hasil penulis akan membahas tentang prosedur penanganan surat keuar di bagian tata usaha pada Lembaga Pendidikan SMP Al-Hasra.

Setelah melakukan Praktek Kerja Lapangan di Lembaga Pendidikan SMP Al-Hasra, penulis cukup merasa puas atas ilmu dan pengalaman yang telah didapat dari para dosen di perkuliahan dan penulis dapat menerapkannya di tempat praktek.

Pada dasarnya, menangani surat-surat keluar adalah kegiatan yang dilakukan hampir setiap hari pada urusan persuratan di Bagian Tata Usaha pada Lembaga Pendidikan SMP AlHasra.

Prosedur penanganan surat keluar yang ada di bagian tata usaha Lembaga Pendidikan SMP Al-Hasra sangat sederhana. Tidak semua langkah-langkah dalam penanganan surat keluar diterapkan di Lembaga Pendidikan SMP Al-Hasra, di karenakan penanganan surat yang kurang dan kesadaran akan pentingnya penanganan surat keluar.

Pada saat penulis melaksanakan praktek kerja lapangan, penulis mendapatkan hasil dan pengalaman serta ilmu yang diperoleh di sebagai berikut :

Macam-macam surat keluar pada Lembaga Pendidikan SMP Al-Hasra ialah surat resmi, surat dinas, surat niaga. Yang dibuat oleh Lembaga Pendidikan SMP Al-Hasra kepada alamat yang dituju dengan menggunakan surat berkop/memiliki kepala surat. 
Pengaruh fungsi surat dalam Lembaga Pendidikan SMP Al-Hasra sangat berpengaruh, kelancaran dan ketertiban administrasi persuratan jika mengalami kendala akan mempengaruhi hasil dari administrasi persuratan.

Draft bagan konsep langkah-langkah surat keluar

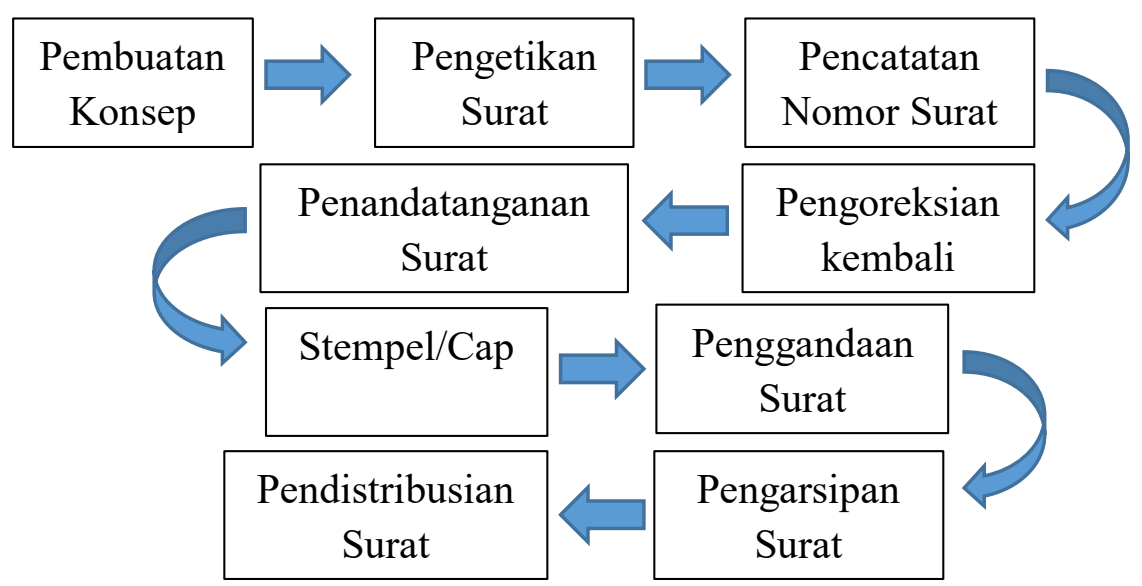

Gambar Langkah-Langkah Penanganan Surat Keluar

Keterangan gambar :

1. Pembuatan konsep naskah/redaksi surat oleh pimpinan, ditulis tangan oleh pimpinan lembaga/instansi.

2. Pengetikan surat setelah pimpinan menuliskan naskah/redaksi surat.

3. Pencatatan nomor surat sesuai dengan nomor di Buku Agenda Surat Keluar.

4. Pengoreksian kembali oleh pimpinan, setelah surat di print out surat tersebut di periksa kembali oleh pimpinan.

5. Penandatanganan oleh pimpinan jika surat sudah siap untuk di distribusikan.

6. Stempel/cap lembaga/instansi agar surat tersebut menjadi resmi.

7. Penggandaan surat, jika surat sudah siap untuk didistribusikan surat tersebut di fotokopi dulu atau digandakan untuk diarsipkan.

8. Pengarsipan surat dengan sistem nomor pada Buku Agenda Surat Keluar, disimpan dalam bindex (map besar).

9. Pendistribusian surat dengan menggunakan Buku Ekspedisi Surat Keluar. 


\section{PENUTUP}

\section{Kesimpulan}

Prosedur penanganan surat keluar di bagian tata usaha pada Lembaga Pendidikan SMP Al-Hasra ialah pembuatan konsep, pengetikan, pencatatan nomor, pengoreksian kembali, stempel/cap, penggandaan, penyimpanan arsip, menulis buku ekpedisi dan pendistribusian.

Pencatatan surat keluar pada lembaga pendidikan SMP Al-Hasra seperti contoh diatas masih menggunakan cara manual yaitu agenda surat keluar. Pencatatan nomor surat dan penyimpanan surat berdasarkan nomor pada surat yang dikeluarkan.

Dengan demikian, dari hasil Praktek Kerja Lapangan penulis selama 2 Bulan diperoleh kesimpulan bahwa Prosedur penanganan surat keluar di Lembaga Pendidikan SMP Al-Hasra masih sangat sederhana, menggunakan buku agenda surat keluar yang cukup baik.

\section{Saran}

Pada dasarnya kinerja dan peran bagian tata usaha ialah administrasi, administrasi pada Lembaga Pendidikan SMP Al-Hasra secara keseluruhan sudah baik, hanya saja dalam penanganan surat keluar masih kurang baik, misalnya dalam penulisan nomor surat kadang ada beberapa nomor surat yang terlewat, penggandaan surat untuk arsip sering lupa.

Dengan melihat kenyataan tersebut di atas maka penulis sampaikan saran-sara sebagai berikut :

1. Mengingat begitu pentingnya surat dalam suatu lembaga/organisasi, maka hendaknya penunjang pengelolaan surat keluar yang baik dengan program/software tersendiri sehingga lebih efektif dan efisien.

2. Kompetensi sumber daya manusia harus lebih di tingkatkan dengan pelatihan dan pembekalan ilmu administrasi agar surat menyurat berjalan dengan efektif dan efisien.

\section{DAFTAR PUSTAKA}

Anggi, Sari, Putri. 2015. Peran Sekretaris Dalam Penanganan Surat Dinas Pada CV Treksindo Duta Media. Tangerang Selatan : Universitas Pamulang.

Apriyani, Wahyu, Eka. Etika Berkomunikasi Dalam Lingkup Kerja, Tangerang Selatan, Universitas Pamulang, 2013. 
Djuharie, Setiawan, O, Suherli dan Teddy Sutandi Komarudin. Surat Menyurat Serbaguna Panduan Korespondensi. Penerbit Yrama Widya.

Herawati, Rosdiana. 2013. Menangani Surat Masuk dan Surat Keluar di Pusat dan Pemberdayaan Pendidik dan Tenaga Kependidikan (PPPTK) Bisnis dan Pariwisata. Tangerang Selatan : Universitas Pamulang.

Hermarianti, Prilli. 2013. Penanganan Surat Masuk Dan Surat Keluar Pada Koperasi Karyawan Pusat Teknologi Informasi Dan Komunikasi Pendidikan (Koppustekkom). Tangerang Selatan : Universitas Pamulang.

http://administrasiumum.blogspot.co.id/2015/06/6-fungsi-surat-secara-umum-yang-perlu.html

Rahman, Beni. 2013. Tatalaksana Surat Menyurat Di Unit Sekretariat Rumah Sakit Bhineka Bakti Husada. Tangerang Selatan : Universitas Pamulang.

Raja, Oskar. 2010. Praktis Membuat Surat Bisnis : 101 Contoh Surat Bisnis, Penerbit L Press.

Suparjati, Dra, Dkk. 2000. Surat Menyurat Dalam Perkantoran . Yogyakarta : Penerbit Kanisius.

Wardhani, Dwi, Latifah, Nur. 2015. Pengelolaan Surat Masuk Dan Surat Keluar Di Unit Pelayanan Teknis Laboraturium Aero-Gas Dinamika Dan Getaran - Badan Pengkajian Dan Penerapan Teknologi, Tangerang Selatan : Universitas Pamulang. 